\title{
Pun Ngai, Migrant Labor in China: Post-Socialist
} Transformations,

Cambridge, UK, Malden, MA, Polity Press, 2016, 204 pp.

Éric Florence

Translator. N. Jayaram

\section{OpenEdition}

Journals

Electronic version

URL: http://journals.openedition.org/chinaperspectives/6999

DOI: 10.4000/chinaperspectives.6999

ISSN: 1996-4617

Publisher

Centre d'étude français sur la Chine contemporaine

\section{Printed version}

Date of publication: 1 June 2016

Number of pages: $72-73$

ISSN: 2070-3449

\section{Electronic reference}

Éric Florence, " Pun Ngai, Migrant Labor in China: Post-Socialist Transformations, », China Perspectives [Online], 2016/2 | 2016, Online since 01 June 2016, connection on 23 September 2020. URL : http:// journals.openedition.org/chinaperspectives/6999; DOI : https://doi.org/10.4000/chinaperspectives. 6999 
could also be accused of having mishandled the event. Besides, the seriousness of the event from the state's viewpoint depends on a variety of factors, especially the number of protestors, the potential material damage, and the extent of media coverage. The latter is a key element in the management of these crises by upper-level authorities. Media pressure on local cadres can in fact render punishment inevitable despite the high political cost. In such cases, it is important to convey an appearance of disciplining to the public, although the decision may be mitigated eventually. There is less elbow room in corruption cases, and discipline cannot amount to a simple transfer, for example, but could mean the end of a career and legal proceedings. Cai shows the important role that information transmitted by the public to the authorities plays in such cases: between $60 \%$ and $80 \%$ of the cases examined by the courts originated from such tips (p. 106). However, only a small portion of such information leads to an inquiry, as most is not sufficiently supported or goes against political considerations. This is especially true with regard to high-level cadres, as proceeding against them requires the discipline inspection commissions to obtain permission from higher authorities, and a political consensus thus becomes necessary. As a result, high-level cadres of the Party-state are rarely disturbed. But when they are, it is with the institution's full might and with serious charges. As a result, despite its differentiated treatment of cases, the regime manages to convey the impression of a certain determination in the anti-corruption struggle.

Finally, Cai deals with two more original aspects of this selective discipline. The first is the circumvention techniques of the cadres themselves and what this implies in terms of tolerance of infringement. Cadres do not remain mute in the face of the disciplining state. To avoid punishment, some suppress information, be it through censoring the press, blocking petitioners, or manipulating inspection teams. They evade blame by playing off different levels of administration and by accusing their colleagues. Besides, some use the relative tolerance of the authorities by playing with the rules in order to advance local reforms. This aspect highlighted by Cai is interesting, as it shows that going against the rules can have a positive effect on local governance. However, by not differentiating the types of reform and thus the potential economic and political impact, the analysis remains superficial, and it is difficult to understand why cadres would take such career risks.

To bring out these different mechanisms, Cai relies on a vast set of written material relating to hundreds of cases of transgressions by agents of the state. While he has occasionally relied on interviews, he gives no details regarding the types of people questioned. Overall, Cai's work offers a good view of the totality of the Chinese Party-state's internal discipline mechanism, detailing its institutions and logic. It also rightfully locates the issue of corruption in a larger framework of state control over its agents, thus going beyond major campaigns with large media coverage.

I Translated by N. Jayaram.

I Jérôme Doyon is a PhD candidate in political science at SciencesPo/CERI (Paris) and Columbia University (New York) (jd2988@columbia.edu).

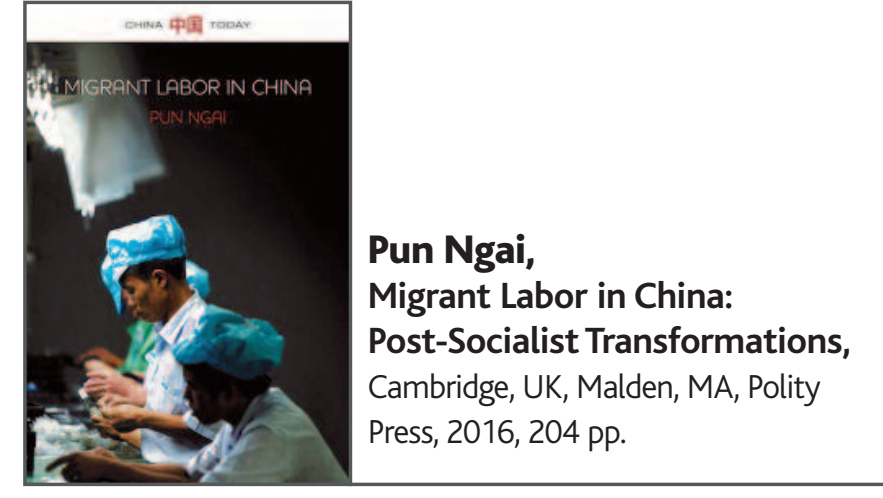

\section{ERIC FLORENCE}

$\mathrm{N}$ oting in the very first chapter that China's socialist development model was challenged systematically for its inability to generate prosperity for its people, Pun Ngai proceeds to explain that she felt compelled to "explore new subjects such as migrant workers" who have paid the "historic debt" of the new economic development model of the post-Maoist era centred on labour commodification and exports (p. 17). While the condition of rural migrant workers remains at the heart of this work, it should be noted at the outset to what extent the book marks a departure from her previous Made in China, ${ }^{(1)}$ published in 2005, which helps explain the intellectual path she has traversed since.

First, while Made in China essentially relied on an ethnographic study of a specific factory in Shenzhen and sought to show how the subjectivity of rural migrant workers was constituted, Migrant Labor in China constitutes the fruits of ten years of work based on several vast research projects that the author and her team initiated and conducted in China. Among them was a major study that brought together 20 tertiary institutions from the People's Republic of China, Hong Kong, and Taiwan conducting more than 3,000 interviews with workers at the Foxconn group following a wave of suicides in 2010 at several of its factories.

Second, in Migrant Labor in China, Pun considers both male and female workers. Moreover, while continuing to focus on the manufacturing industry, she has over the past five years enlarged her investigation to include the construction industry and its workers. Pun shows how different institutional measures and political decisions starting in 1984 allowed the development of a pyramidal system of subcontracting in which a decoupling occurs between higher levels of construction project managements (property developers and construction companies) and the implementation of projects left to different subcontractors, a system notably leading to numerous instances of non-payment of wages, the absence of contractual relations between the worker and the employer, and the impossibility of direct contact between construction workers and the boss. Pun also shows how this political economy of the construction sector shapes the ways of protestation - in general violent and often outside legal avenues (pp. 41-56). As for forms of contestation in the manufacturing sector, which is tending towards radicalisation, Pun documents how migrant workers profiting from a process of long-term accumulation of experience have managed to proactively mobilise in their daily struggles a range of increasingly vast resources, institutional and non-institutional, individual and collective. Globally, in both the construction and manufacturing industries, different forms of alliances have

1. Pun Ngai, Made in China, Durham, NC, Duke University Press, 2005. 
solidified between local state power and transnational economic forces, helping generate considerable surplus value to the detriment of workers' security and health and in some cases even their lives.

Third, the voices and personalities of migrant workers are on the whole less present than in Made in China. The book pays greater attention to the structures of domination and to the political economy of the sectors studied. Perhaps this evolution in the author's work reflects a more pronounced mobilisation of Marxist-inspired analytical tools. It appears that the lesser attention to ethnographic details in Migrant Labor in China nevertheless permits a more profound description of politico-institutional, legal, and economic configurations behind the functioning of contemporary industrial capitalism and its complex modalities of reinvention and redeployment. Of course this stress on domination was already present in the author's previous work. In particular, her first article in 1999 (2) minutely described the spatio-temporal control over female workers in the production regime of a Shenzhen factory, combining Foucauldian and Marxist approaches; or again her description of the triple constraints - patriarchy, Party-state, and global capitalism - fashioning the subjectivity of rural women when it comes to their decision to leave their villages. But in Migrant Labor in China, Pun goes beyond descriptions of a specific production regime or political economy of labour in Shenzhen in particular, in order to expose politico-institutional processes in the countryside and in urban zones that have led to the development of a labour market largely benefiting capital accumulation, engendering what the author terms an "unfinished process of proletarianization" enabling "a production regime within which a separation exists between the production sphere in industrial regions and social reproduction in rural areas" (pp. 33-34). Migrant Labor in China also sheds light on the transformations in contemporary industrial capitalism through the study of the Foxconn group, which represents, according to the author, an example of concentration and centralisation of capital on "an unimaginable scale," an exemplar of "monopoly capitalism" (p. 105). Pun shows how in a context of rarefaction of labour in China's coastal regions and a greater awareness of legal rights among workers, the IT giant $(1,400,000$ workers employed in China in 2010) managed to redeploy its production centres to interior regions (southwest, central, and north). This redeployment documented in the book reveals a great capacity for resilience among enterprises, especially in institutionally creating, with the active mediation of regional and local governments, new sources of labour that are more vulnerable and more easily exploitable. ${ }^{(3)}$ This is not without recalling similar processes studied previously at the level of history of global capitalism. (4)

Finally, the book also contains interesting information on the "second generation of migrant workers" (those born in the late 1980s and in the 1990s). The absence of predictability, security, and dignity defines in a more determining manner the condition and identity of migrant workers, as well as their modes of resistance and contestation of domination structures (p. 150). The author stresses that while differences between first and second generation workers should not be exaggerated, the second generation is on the whole more individualistic, better educated, clearly more oriented towards urban culture and consumption, and animated by an experience of indignity so pronounced that they nurture neither the hope of remaining in the city nor of returning to their native villages. In Pun's view, while the first generation of workers was characterised by the ephemeral nature of its condition, the second is characterised more by the notion of "rupture" through resentment and anger (p. 80).
To conclude, it may be pointed out that some chapters in the book rework articles previously published in journals by updating them and rendering them more accessible to readers who are not China experts or specialists in the political anthropology of labour. This effort at readability makes this work, which clearly articulates theoretical issues and concrete human experiences, accessible to a larger public. It should interest students, researchers, and teachers in the domain of contemporary Chinese studies and human and social sciences.

I Translated by N. Jayaram.

I Eric Florence is director of the CEFC (eflorence@cefc.com.hk).

2. Pun Ngai, "Becoming Dagongmei: The Politics of Identity and Difference in Reform China," The China Journal, No. 42, July 1999, pp. 1-19.

3. In Foxconn's case it took the form of recourse to trainees from vocational schools, with the help of municipal authorities in charge of employment and education, thus contravening labour laws.

4. See Robin Cohen, The New Helots: Migrants in the International Division of Labour, Cower, Aldershot, 1987.

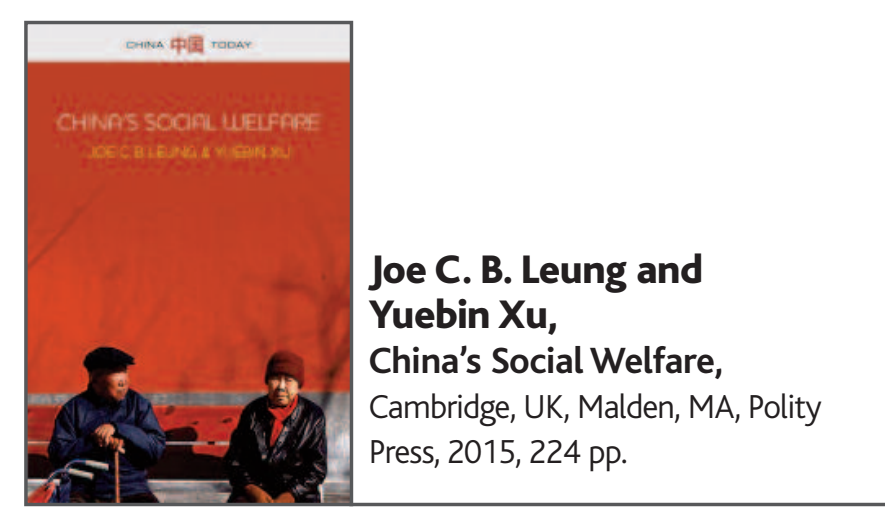

\section{CARINE MILCENT}

W ritten by Joe C. B. Leung and Yuebin Xu, China's Social Welfare: The Third Turning Point is a book that, within the space of some 200 pages, manages to describe the structure of China's major institutional developments in "social welfare," examining them from a historical perspective, as well as within the country's economic, demographic, legal, and social contexts.

China's new social welfare system covers the social protection system and its eligibility (social security benefits and pensions) as well as social services, and their accessibility in both financial and geographical terms. However, it also calls into question the notion of an egalitarian society and the level of economic development required to provide such wellbeing (xiaokang). This term is often associated with terms such as wellbeing, social development, and social policy. According to the definition coined by Elizabeth Segal in 2010 (Social Welfare Policy and Social Programs: A Value Perspective, Belmont, Brooks/Cole), then echoed by the authors: "In a wider perspective, it is the collective response to social problems."

The first publications to tackle the issue of social welfare began to appear throughout the 1980s. One of these was Dixon's Chinese Social Welfare System, 1949-1979, published in 1981 and among the first to provide data on the Maoist era. Other publications would follow throughout the 1990s, such as Cecilia Chan and Nelson Chow's More Welfare after Economic Reform? Welfare Developments in the People's Republic of China (1992), in 